\title{
Momento de realização da inseminação artificial ou monta natural em relação à ovulação e sua interferência na determinação do sexo do concepto
}

Giovanna Takakura ${ }^{[a]}$, Ariane Flávia do Nascimento ${ }^{[b]}$, Afonso Celso Junqueira Borges ${ }^{[a]}$, Taiguara de Castro Sampaio ${ }^{[a]}$, Carolina Coimbra Chagas[c]

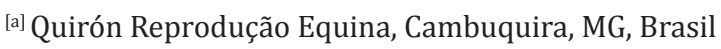 \\ ${ }^{[b]}$ Fundação de Ensino e Tecnologia de Alfenas (UNIFENAS/FETA), Alfenas, MG, Brasil \\ [c] Universidade Federal de Lavras (UFLA), Lavras, MG, Brasil
}

*Autor correspondente

e-mail: gstakakura@yahoo.com.br

\section{Resumo}

A definição do sexo do concepto é determinada por genes contidos no cromossomo X ou Y do espermatozoide no momento em que ocorre a fecundação do oócito. Os espermatozoides que contém o cromossomo Y são mais leves, mais rápidos, menos resistentes e quando fecundam o oócito que contém o cromossomo X resultam na formação de embriões que ao se desenvolverem geram indivíduos machos. Os espermatozoides que contém o cromossomo X são mais pesados, mais lentos e mais resistentes, e ao se fundirem ao oócito geram embriões que darão origem a indivíduos fêmeas. Tendo em vista a preferência por nascimento de potras, a campo percebe-se resistência dos proprietários em realizar a inseminação artificial ou monta natural em momentos próximos da ovulação. Tal hesitação é justificada pela possibilidade dos espermatozoides $Y$, sendo mais rápidos, favorecerem a maior concepção de potros em relação ao de potras. Objetivou-se, assim, conhecer a proporção de potras e potros nascidos, relacionando o tempo transcorrido entre a inseminação artificial (ou monta natural) e a ovulação. Os dados foram coletados em animais da raça Mangalarga Marchador pela equipe da Quirón Reprodução Equina, com sede na Fazenda Nossa Senhora Aparecida, município de Cambuquira, no sul de Minas Gerais. Foi realizado um levantamento do sexo de potros nascidos que haviam sido produzidos em estações de monta anteriores (2011 a 2015), totalizando 193 animais. Foram coletados nascimentos dos quais havia anotação sistemática diária do ciclo reprodutivo da doadora ou matriz. Os dados incluíam o dia da indução da ovulação, o dia da inseminação ou monta natural e o dia da ovulação. Os resultados foram agrupados em número de machos e número de fêmeas gerados a partir de ciclos nos quais a inseminação foi realizada de 48 a 24 horas antes da ovulação (76 indivíduos - grupo 1), de 24 horas ao momento da ovulação (111 indivíduos - grupo 2) e até 6 horas após 
a ovulação ( 6 indivíduos - grupo 3). Não houve diferença significativa. No grupo 1 a taxa de nascimentos de machos foi de $48,68 \%$ ( 37 potros) e a de fêmeas de $51,32 \%$ (39 potras). No grupo 2 , a taxa de nascimento de machos foi de $51,35 \%$ (57 potros) e a de fêmeas de $48,65 \%$ (54 potras). No grupo 3 , a taxa foi $50 \%$ de machos e 50\% de fêmeas. Perfazendo no total, de 193 nascimentos, 97 do sexo masculino e 96 do sexo feminino. Tais resultados comprovam que não apenas a velocidade ou longevidade do espermatozoide determinarão a fecundação por Y ou X. Outros fatores como o pH dos fluídos vaginais, $\mathrm{pH}$ do fluído seminal do garanhão e osmolaridade estão envolvidos na perda da capacidade fertilizante que ocorre antes da perda da motilidade. Em suma, o espermatozoide que fecunda é o que alcança o oócito com sua capacidade de fecundação intacta.

Palavras-chave: Proporção. Machos. Fêmeas. 